\title{
HWMA/RCRA Closure Plan for the CPP-602 Laboratory Lines
}

September 2009 

DOE/ID-11406

Rev. 0

\section{HWMA/RCRA Closure Plan for the CPP-602 Laboratory Lines}

September 2009 



\section{ABSTRACT}

This Hazardous Waste Management Act/Resource Conservation and Recovery Act Closure (HWMA/RCRA) Plan for the CPP-602 laboratory lines was developed to meet the tank system closure requirements of the Idaho Administrative Procedures Act 58.01.05.008 and 40 Code of Federal Regulations 264, Subpart G. CPP-602 is located at the Idaho Nuclear Technology and Engineering Center at the Idaho National Laboratory Site. The lines in CPP-602 were part of a liquid hazardous waste collection system included in the Idaho Nuclear Technology and Engineering Center Liquid Waste Management System Permit. The laboratory lines discharged to the Deep Tanks System in CPP-601 that is currently being closed under a separate closure plan.

This closure plan presents the closure performance standards and the methods for achieving those standards. The closure approach for the CPP-602 laboratory lines is to remove the lines, components, and contaminants to the extent practicable. Comprehensive Environmental Response, Compensation, and Liability Act (CERCLA) Site CPP-117 includes the CPP-602 waste trench and the area beneath the basement floor where waste lines are direct-buried. Upon completion of rinsing or mopping to remove contamination to the extent practicable from the waste trench and rinsing the intact buried lines (i.e., stainless steel sections), these areas will be managed as part of CERCLA Site CPP-117 and will not be subject to further HWMA/RCRA closure activities.

The CPP-602 building is being decontaminated and decommissioned under CERCLA as a non-time critical removal action in accordance with the Federal Facility Agreement/Consent Order. As such, all waste generated by this CERCLA action, including closure-generated waste, will be managed in coordination with that CERCLA action in substantive compliance with HWMA/RCRA regulations. All waste will be subject to a hazardous waste determination for the purpose of supporting appropriate management and will be managed in accordance with this plan. 


\section{CONTENTS}

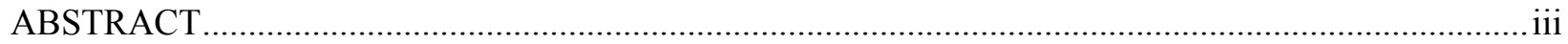



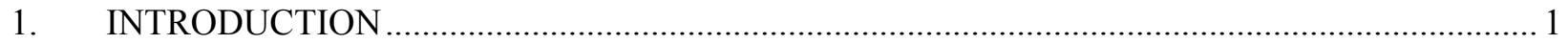

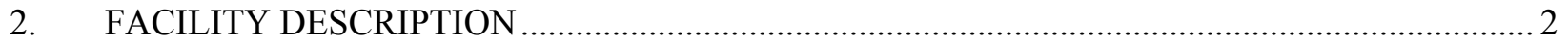

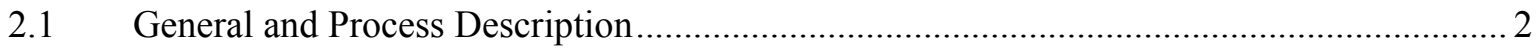

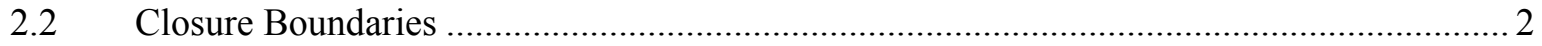

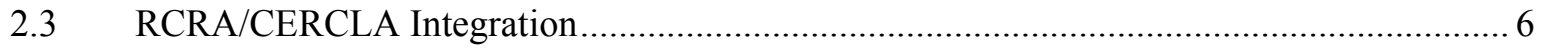

2.3.1 CERCLA Non-Time Critical Removal Action .............................................. 6



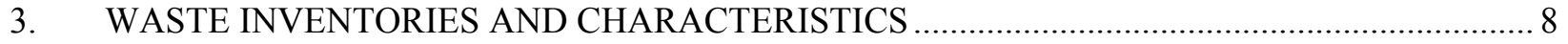

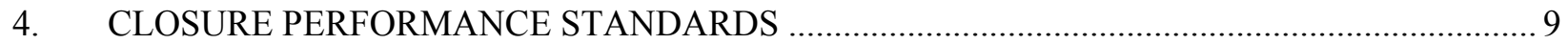

4.1 Regulatory Closure Performance Standards ................................................................ 9

4.2 Required Activities for Achieving Closure Performance Standards ................................. 9

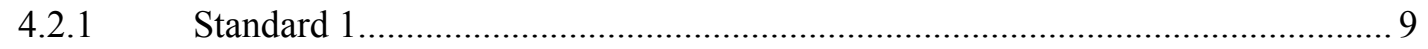

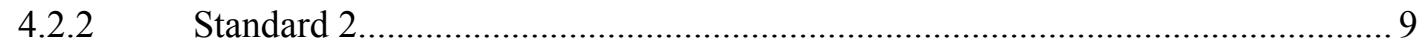

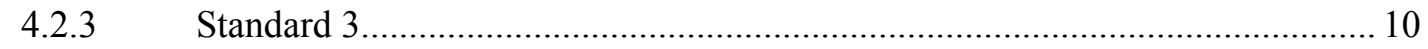

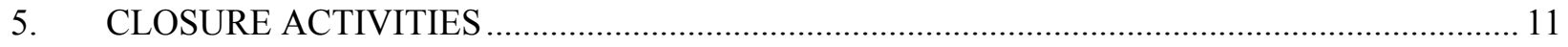



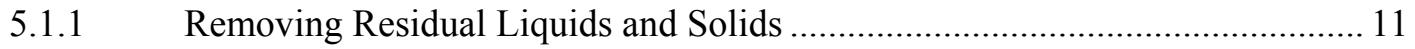

5.1.2 Rinsing Buried Waste Lines and Waste Trench.............................................. 11

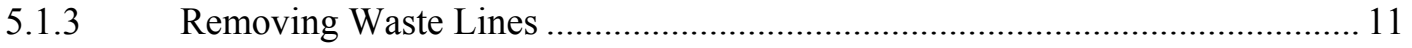



5.2.1 Waste Removed from the Tank System Components..................................... 12

5.2.2 Regulated Lines Subject to Waste Management Level Determination.............. 12

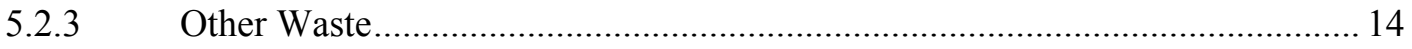



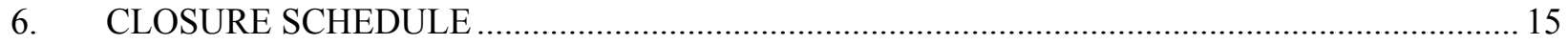

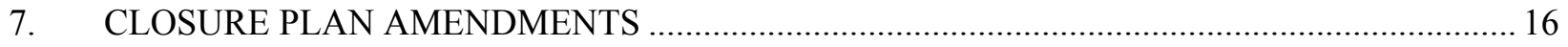

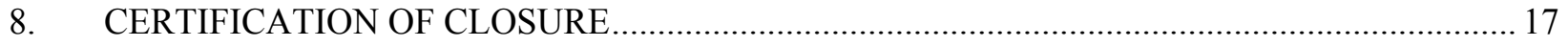

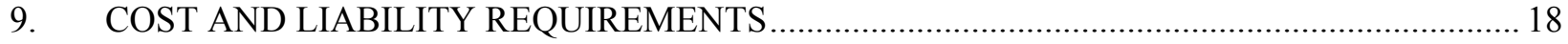

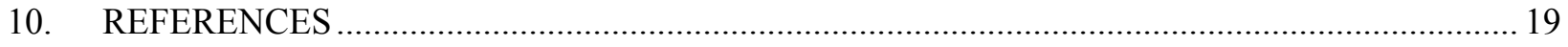

Appendix A-CPP-602 System Components and Boundaries.......................................................... 21 


\section{FIGURES}

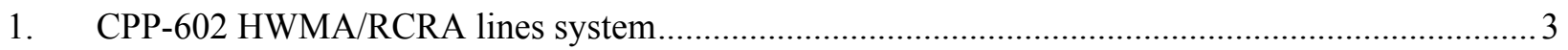

2. End view of CPP-602 waste trench and buried lines within CERCLA Site CPP-117 _................... 4

3. Plan view of basement of CPP-602 waste trench and buried lines within CERCLA Site CPP-117... 5

\section{TABLES}



2. Contaminants of concern and corresponding waste management levels. ....................................... 13

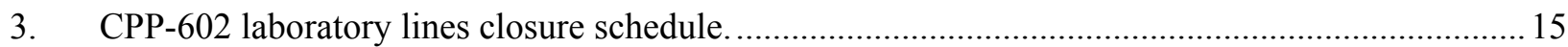




\section{ACRONYMS}

CERCLA Comprehensive Environmental Response, Compensation, and Liability Act

CFR Code of Federal Regulations

DEQ Idaho Department of Environmental Quality

D\&D decontamination and decommissioning

EPA U.S. Environmental Protection Agency

HWMA Hazardous Waste Management Act

IDAPA Idaho Administrative Procedures Act

INL Idaho National Laboratory

INTEC Idaho Nuclear Technology and Engineering Center

OU operable unit

PE professional engineer

RCRA Resource Conservation and Recovery Act

TSDF treatment, storage, and disposal facility 


\section{HWMA/RCRA Closure Plan for the CPP-602 Laboratory Lines}

\section{INTRODUCTION}

This Hazardous Waste Management Act (HWMA) (Idaho Code $\S 39-4401$ et seq. 1983)/Resource Conservation and Recovery Act (RCRA) (42 USC 6901 et seq. 1976) closure plan has been prepared to address the closure of the CPP-602 laboratory lines located at the Idaho Nuclear Technology and Engineering Center (INTEC) at the Idaho National Laboratory (INL) Site.

The CPP-602 laboratory lines were part of a liquid hazardous waste collection system that is included in the Partial Permit for the HWMA Storage and Treatment for the Liquid Waste Management System at the Idaho Nuclear Technology and Engineering Center on the Idaho National Laboratory (State of Idaho 2008). The CPP-602 laboratory lines discharged to the CPP-601 Deep Tanks System, which was part of the Liquid Waste Management System and is being closed under a separate closure plan. Because the CPP-602 laboratory lines are considered associated ancillary lines and equipment to that system, this closure plan was developed in compliance with HWMA/RCRA regulations to meet the tank system closure requirements of Idaho Administrative Procedures Act (IDAPA) 58.01.05.008 and 40 Code of Federal Regulations (CFR) 264, Subparts 111 and 197.

This HWMA/RCRA closure plan includes a description of the CPP-602 laboratory lines, the current and maximum hazardous waste inventory and applicable U. S. Environmental Protection Agency (EPA) hazardous waste numbers, and a description of the closure activities that will be conducted to meet the closure performance standards. The closure approach specified in this closure plan is removing, to the extent practicable, the contamination and components used to collect and convey hazardous waste to the collection and storage part of the permitted system in CPP-601. Decontamination and waste management activities will be conducted in coordination with the Idaho Cleanup Project Comprehensive Environmental Response, Compensation, and Liability Act (CERCLA) Program as discussed in Section 2.3.

Because the part of the tank system being closed is included in the Partial Permit for the INTEC Liquid Waste Management System (State of Idaho 2008), upon approval by the Idaho Department of Environmental Quality (DEQ), this closure plan will be incorporated as an attachment to the modified permit. The CPP-602 laboratory lines will be considered HWMA/RCRA clean closed in accordance with 40 CFR 264.111 and 264.197 when the closure activities identified in the plan are complete, as certified by a qualified professional engineer (PE). The CPP-602 laboratory lines will be certified as closed in accordance with the tank system closure requirements of IDAPA 58.01.05.008 and 40 CFR 264.111 and 264.197. 


\section{FACILITY DESCRIPTION}

\subsection{General and Process Description}

The CPP-602 laboratory lines include associated ancillary lines and equipment within the boundaries of the CPP-602 Analytical Laboratory as defined in this closure plan. The CPP-602 laboratory lines are included in the Partial Permit for HWMA Storage and Treatment for the Liquid Waste Management System at the Idaho Nuclear Technology and Engineering Center on the Idaho National Laboratory (State of Idaho 2008), which is permitted for tank storage and treatment of hazardous waste.

A general description and a process description of the INTEC Liquid Waste Management System and associated subsystems are included in Attachment 1, Appendix B, of the partial permit. The CPP-602 laboratory waste discharge lines are included in the partial permit as inputs to the CPP-601 storage and treatment tank system (WG/WH Deep Tanks). The CPP-602 facility was constructed in the early 1950s to support general wet-chemistry analyses using hands-on procedures. The CPP-602 Analytical Laboratory contains chemistry and instrumentation laboratories. The laboratories provided a full range of routine analytical capability including inorganic, organic, and radioanalytical analyses in support of process and waste characterization, especially to meet regulatory requirements.

The CPP-602 laboratory waste discharge lines managed waste from the laboratory hoods, sinks, and drains discharging to the CPP-601 Deep Tanks, which are undergoing closure. For the purposes of this closure plan, the CPP-602 lines being closed are defined as the laboratories' waste discharge lines shown in Figure 1 and detailed in Appendix A, Table A-1.

\subsection{Closure Boundaries}

HWMA/RCRA requires closure of the tank system, including all ancillary equipment that was used to manage hazardous waste. The tank system ancillary components being closed under this closure plan are the waste line components within CPP-602 (see Figure 1). The CPP-602 drain lines are included from the lines that exit the sinks and hoods in the CPP-602 Laboratories A-E and caves, to the main CPP-602 line headers in the CPP-602 waste trench that connect to the CPP-601 line header in the LC-107 sump.

A list of tank system components addressed under this closure plan is provided in Table A-1. The closure boundaries, as identified in Figure 1 and Table A-1, were established to define the breakpoints between the CPP-602 laboratory lines and the remainder of the CPP-601 Deep Tanks System, including the remainder of the active INTEC Liquid Waste Management System. The remainder of the INTEC Liquid Waste Management System outside CPP-601 and CPP-602 remains operational.

CERCLA Site CPP-117 includes the CPP-602 waste trench and the area beneath the basement floor where waste lines are direct-buried (see Figures 2 and 3.). Upon completion of rinsing or mopping to remove contamination to the extent practicable from the waste trench and rinsing the intact buried lines (i.e., stainless steel sections), these areas will be managed as part of CERCLA Site CPP-117 and will not be subject to further HWMA/RCRA closure activities. 


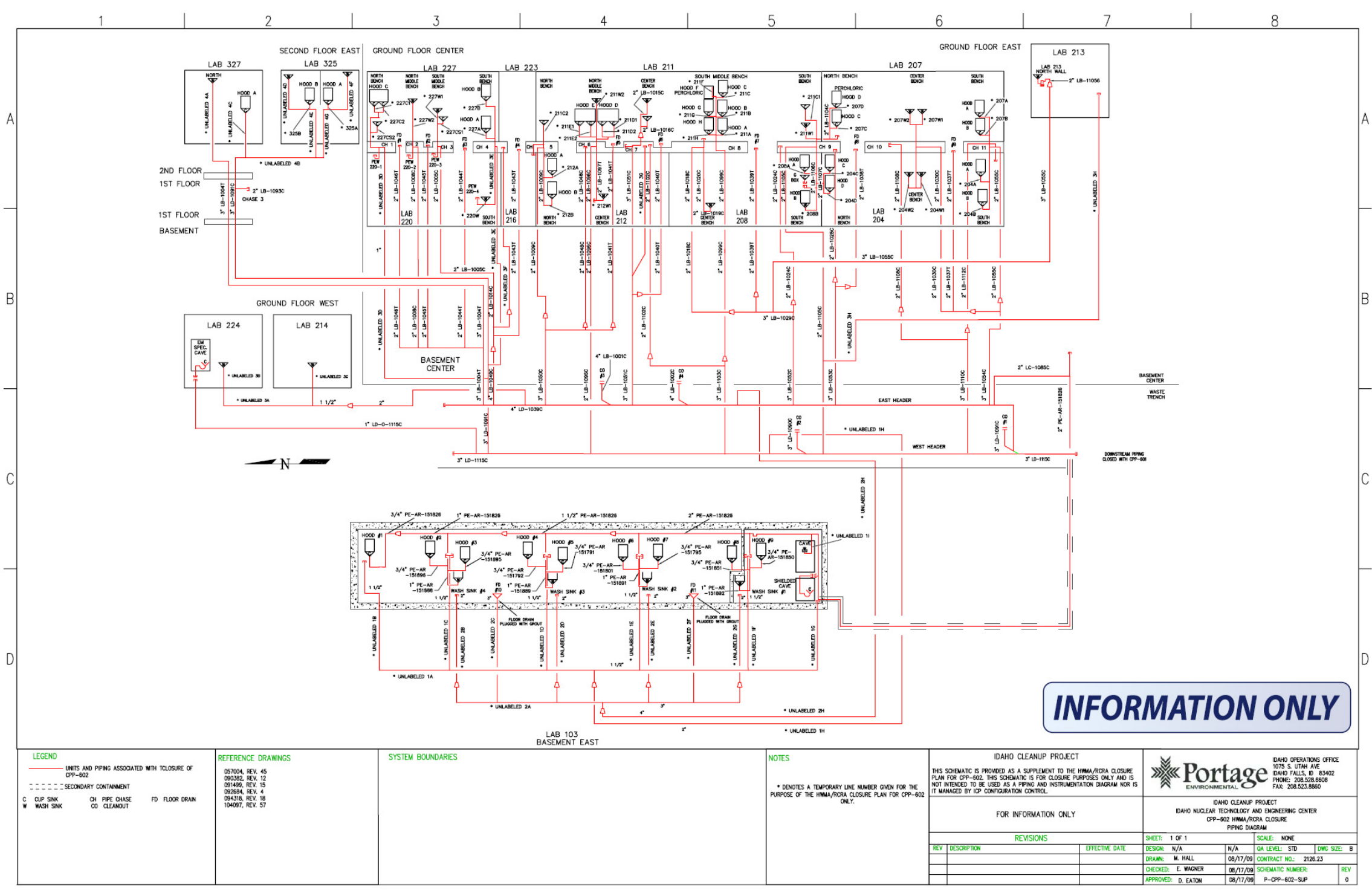

Figure 1. CPP-602 HWMA/RCRA lines system. 


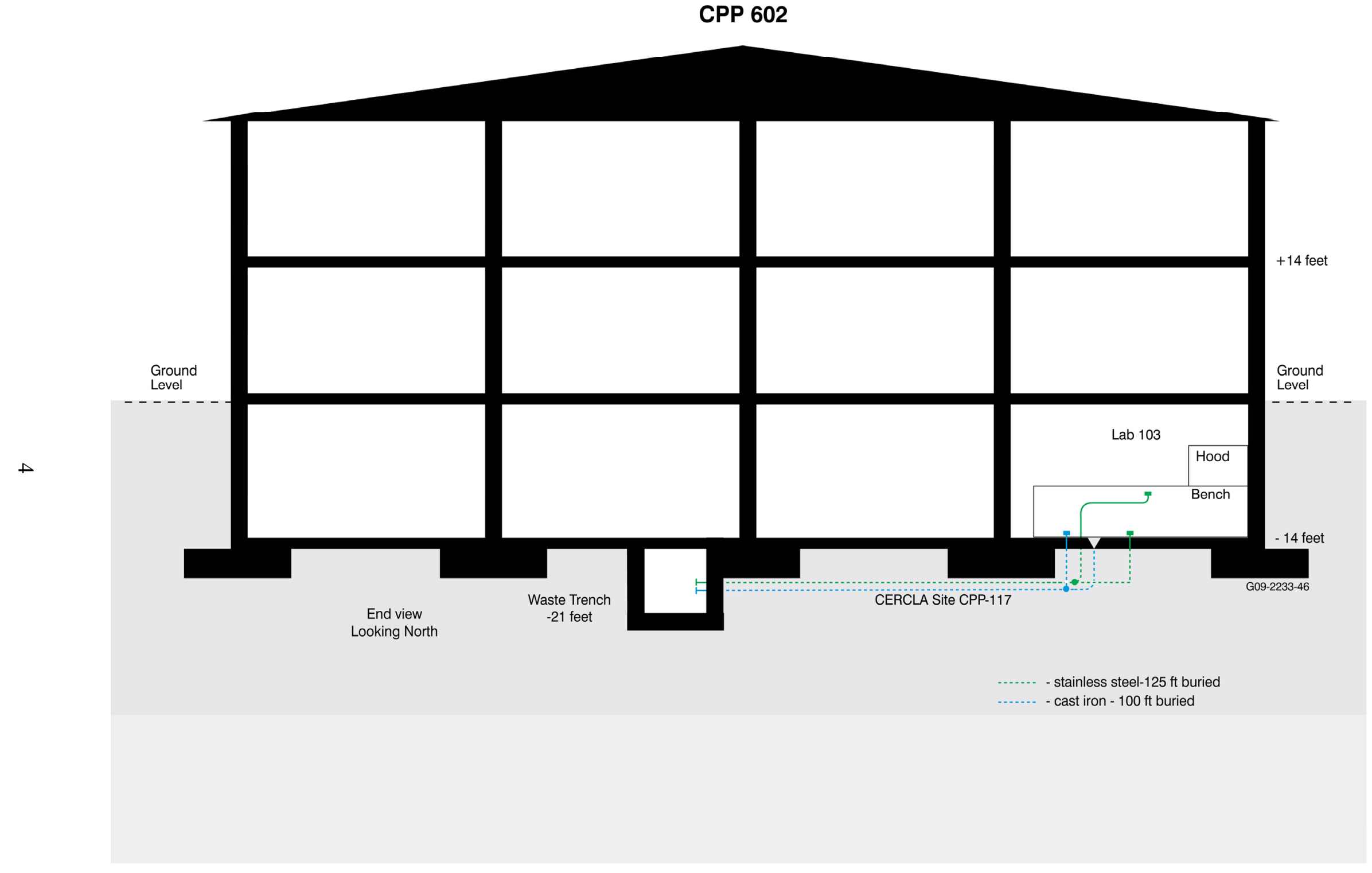

Figure 2. End view of CPP-602 waste trench and buried lines within CERCLA Site CPP-117. 


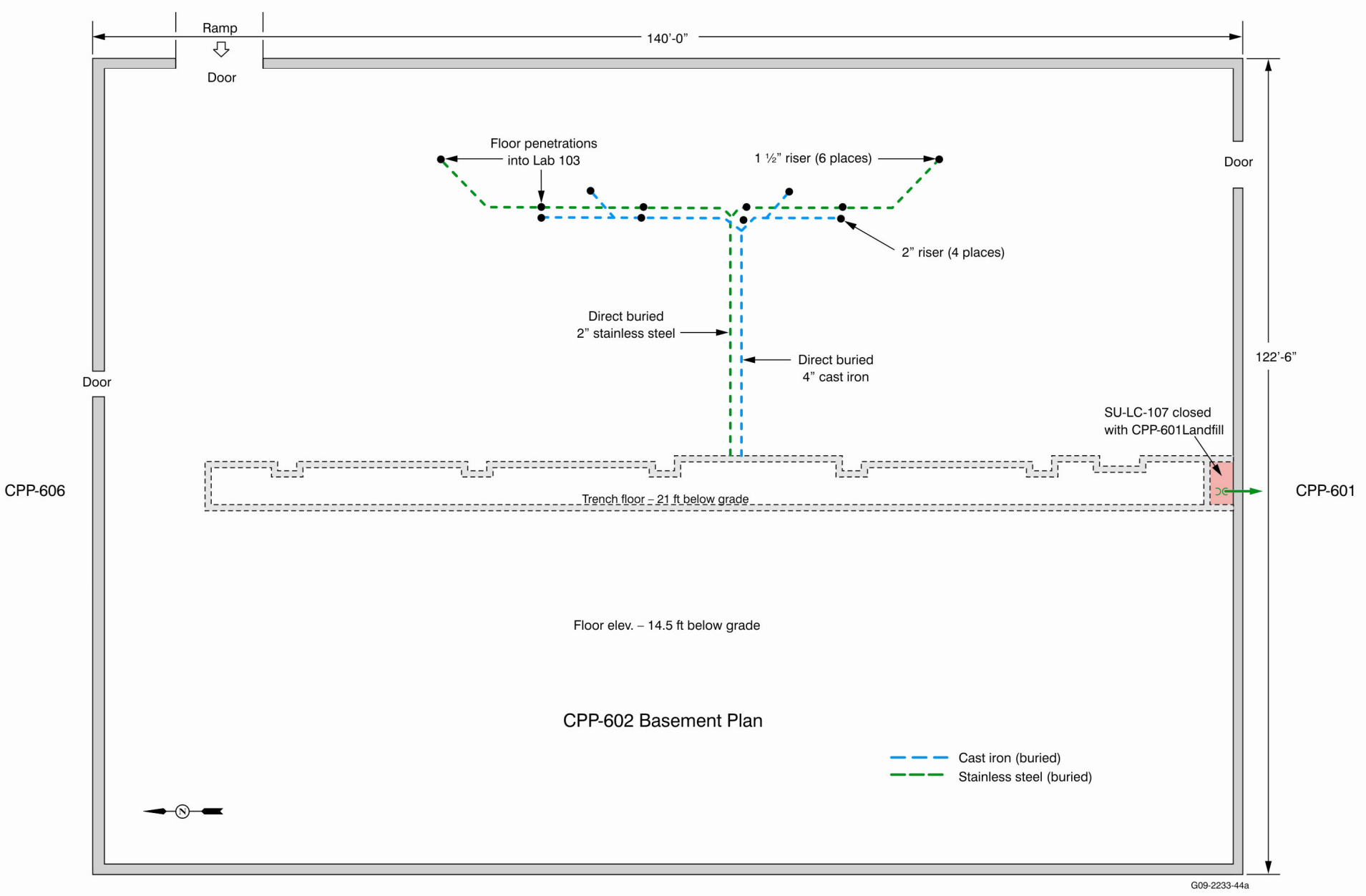

Figure 3. Plan view of basement of CPP-602 waste trench and buried lines within CERCLA Site CPP-117. 


\subsection{RCRA/CERCLA Integration}

\subsubsection{CERCLA Non-Time Critical Removal Action}

Building CPP-602 is being decontaminated and decommissioned (D\&D) under CERCLA as a non-time critical removal action under the Action Memorandum for General Decommissioning Activities under the Idaho Cleanup Project (DOE-ID 2009a). All waste generated from the non-time critical removal action, including the waste generated under this closure plan, will be managed as CERCLA waste in substantive compliance with the generator requirements of 40 CFR 262 (i.e., administrative requirements, such as time limits for storage, are not substantive other than those timeframes specifically identified in this closure plan). As documented in Section 5.2, "Waste Management," all of the waste removed from regulated piping, as well as that piping that does not meet the waste management action levels, will be sent to RCRA-permitted treatment, storage, and disposal facilities (TSDFs). All other waste generated from the D\&D and closure of this building will be disposed of at an approved CERCLA facility, such as the Idaho CERCLA Disposal Facility.

\subsubsection{CPP-117 Existing CERCLA Site}

CERCLA Site CPP-117 addresses the contamination below CPP-602 that resulted from releases from direct-buried piping beneath the basement floor, the waste trench, and the waste trench sump. This site was originally identified as CPP-86 when contamination beneath the waste trench sump was identified in the late 1980s. CPP-86 was later incorporated into CPP-117 when a CERCLA New Site Identification Form was submitted to the CERCLA Agencies for their concurrence. CPP-117 addresses the area beneath the waste piping, as well the waste trench and waste trench sump. The Operable Unit (OU) 3-14 Record of Decision (DOE-ID 2007) determined that CPP-117 should be cleaned up under OU 3-13 in accordance with the process identified in the Operable Unit 3-13 Group 2 Closure Evaluation Criteria and Checklist (DOE-ID 2000) using the OU 3-14 remediation goals.

Two line segments are buried beneath the CPP-602 basement floor. The first line segment consists of the cast iron cold waste lines that received waste from floor drains and wash sinks. The only times that significantly contaminated material was likely to have been transferred through this line segment would have been as the result of spill cleanup activities that might have flushed contaminants down those drains. This line segment was in operation from its inception, in 1953, to 1990 when these lines were discovered to no longer be intact. At this time, these lines were abandoned in place by sealing the drains and taking the lines out of service.

The other buried line segment consists of the stainless steel hot waste lines that received waste from the hot sinks within the laboratory hoods. These hot sinks were routinely used to dispose of excess sample material and other laboratory waste from 1953 until the system was replaced by a RCRA-compliant waste collection system in 1990. At that time, these stainless steel lines were abandoned in place by isolating and sealing the remaining piping while connecting the hot sink drains to the new piping system.

In addition to the area surrounding the two direct-buried line segments, CERCLA Site CPP-117 includes the waste trench, waste trench sump, and the soils beneath. The releases from the waste trench sump were discovered in 1990, but are expected to have occurred over a period between the inception of operations in 1953 to when the release was discovered. Upon discovery, the sump system was modified to add a stainless steel liner. 
2.3.2.1 Characterization Information. The soil 6 in. below the waste trench sump was sampled in 1990. Toxicity characteristic leaching procedure results showed low levels of barium, cadmium, chromium, and mercury. Non-detects were reported for arsenic, lead, selenium, and silver. All values were well below the HWMA/RCRA characteristic level as shown in the Table 1. These constituents were also evaluated under CERCLA for risk and were determined to not represent an unacceptable risk (less than 1E-8).

Table 1. CPP-602 waste trench sump soil sample results.

\begin{tabular}{lcccc}
\hline \multicolumn{1}{c}{ Constituent } & $\begin{array}{c}\text { TCLP } \\
(\mathrm{mg} / \mathrm{L})\end{array}$ & Lab Flag & $\begin{array}{c}\text { HWMA/RCRA } \\
\text { Characteristic Level } \\
(\mathrm{mg} / \mathrm{L})\end{array}$ & $\begin{array}{c}\text { Less than } \\
\text { Characteristic } \\
\text { Level? }\end{array}$ \\
\hline Arsenic & 0.065 & $\mathrm{U}$ & 5.0 & Yes \\
Barium & 0.76 & 100.0 & Yes \\
Cadmium & 0.46 & 1.0 & Yes \\
Chromium & 0.0253 & 5.0 & Yes \\
Lead & 0.080 & $\mathrm{U}$ & 5.0 & Yes \\
Mercury & 0.054 & & 0.2 & Yes \\
Selenium & 0.115 & $\mathrm{U}$ & 1.0 & Yes \\
Silver & 0.007 & $\mathrm{U}$ & 5.0 & Yes \\
\hline HWMA Hazardous Waste Management Act & & \\
RCRA Resource Conservation and Recovery Act & & \\
TCLP toxicity characteristic leaching procedure & & \\
$\mathrm{U}$ & undetected
\end{tabular}

Samples have not been collected beneath the release point in the cast iron lines. However, because those lines were not routinely used for the disposal of contaminated waste, it is expected that the contamination within the soils surrounding these lines would be bounded by the contamination found beneath the sump where higher levels of contamination would be expected. While the cast iron lines would not normally have had HWMA/RCRA-listed waste discharged through them, the cast iron lines may have had characteristic materials flushed through them (e.g., as a result of spill cleanup). There is no reason to expect HWMA/RCRA-listed waste to have been disposed of through those lines.

2.3.2.2 CERCLA Management. As part of the closure of the regulated lines within CPP-602, the cast iron buried lines will be isolated and sealed. The stainless steel buried lines will be triple rinsed, isolated, and sealed. The waste trench will be rinsed or mopped to remove contamination to the extent practical. The piping will be removed from the waste trench sump, but the sump itself is being addressed as part of the CPP-601 landfill closure. Because the rest of the historic release sites beneath CPP-602 are being addressed as CERCLA OU 3-13 Group 2 sites under the Federal Facilities Act/Consent Order, they are not addressed further in this closure plan. 


\section{WASTE INVENTORIES AND CHARACTERISTICS}

This section provides maximum waste inventories and waste characteristics for the CPP-602 laboratory lines. The waste discharge lines from the CPP-602 laboratories have been rinsed to the extent practicable and are gravity-draining. Therefore, this line system is not expected to contain bulk hazardous waste except for small amounts of liquid or solid waste held up within the P-traps beneath sinks or hoods. As a group, these P-traps are expected to contain no more than 10 gallons of waste. This would represent the maximum waste inventory within the CPP-602 regulated lines system at any time.

The CPP-602 discharge lines are permitted to manage the following wastes and associated EPA hazardous waste numbers:

- Wastes exhibiting the characteristic of ignitability (D001)

- Wastes exhibiting the characteristic of corrosivity (D002)

- Wastes exhibiting the toxicity characteristic for arsenic (D004), barium (D005), cadmium (D006), chromium (D007), lead (D008), mercury (D009), selenium (D010), silver (D011), benzene (D018), carbon tetrachloride (D019), chlorobenzene (D021), chloroform (D022), cresol (D026), 1,2-dichloroethane (D028), hexachlorobenzene (D032), hexachloroethane (D034), methyl ethyl ketone (D035), nitrobenzene (D036), pyridine (D038), tetrachloroethylene (D039), or trichloroethylene (D040)

- $\quad$ Spent halogenated and nonhalogenated solvent wastes assigned EPA-listed hazardous waste numbers F001, F002, F003, or F005

- $\quad$ Discarded commercial chemical products, off-specification species, container residues, and spill residues assigned EPA-listed hazardous waste number U134. 


\section{CLOSURE PERFORMANCE STANDARDS}

This section describes the performance standards for closure of the CPP-602 laboratory lines (IDAPA 58.01.05.008 [40 CFR 264.111 and 264.197]) and the activities that will be conducted to demonstrate that the closure performance standards have been met.

\subsection{Regulatory Closure Performance Standards}

The closure performance standards identified in IDAPA 58.01.05.008 (40 CFR 264.111 and 264.197) applicable to the CPP-602 laboratory lines closure are:

1. The owner or operator must close the facility in a manner that minimizes the need for further maintenance (IDAPA 58.01.05.008 [40 CFR 264.111(a)])

2. The owner or operator must close the facility in a manner that controls, minimizes, or eliminates to the extent necessary to protect human health and the environment, post-closure escape of hazardous waste, hazardous constituents, leachate, contaminated runoff, or hazardous waste decomposition products to the ground or surface waters or to the atmosphere (IDAPA 58.01.05.008 [40 CFR 264.111(b)])

3. The owner or operator must close the facility in a manner that complies with the closure requirements of this subpart, including, but not limited to, the requirements of 40 CFR 264.197, 264.228, 264.258, 264.280, 264.310, 264.351, and 264.1102 (IDAPA 58.01.05.008 [40 CFR 264.111(c)]).

\subsection{Required Activities for Achieving Closure Performance Standards}

The CPP-602 laboratory lines closure and waste management activities to be conducted under HWMA/RCRA closure are described in detail in Section 5. The closure performance standards will be achieved as described in the following subsections.

\subsubsection{Standard 1}

The owner or operator must close the facility in a manner that minimizes the need for further maintenance (IDAPA 58.01.05.008 [40 CFR 264.111(a)]).

This closure performance standard will be achieved as follows:

- $\quad$ Residual hazardous waste inventory will be removed and managed as specified in Subsection 5.1

- $\quad$ Tank system lines and equipment undergoing HWMA/RCRA closure will be removed and managed as specified in Subsection 5.2.

\subsubsection{Standard 2}

The owner or operator must close the facility in a manner that controls, minimizes, or eliminates to the extent necessary to protect human health and the environment, post-closure escape of hazardous waste, hazardous constituents, leachate, contaminated runoff, or hazardous waste decomposition products to the ground or surface waters or to the atmosphere (IDAPA 58.01.05.008 [40 CFR 264.111(b)]). 
This closure performance standard will be achieved as follows:

- $\quad$ Residual hazardous waste inventory will be removed and managed as specified in Subsection 5.1

- $\quad$ Tank system lines and equipment undergoing HWMA/RCRA closure will be removed and managed as specified in Subsection 5.2.

\subsubsection{Standard 3}

At closure of a tank system, the owner or operator must remove or decontaminate all waste residues, contaminated containment system components (liners, etc.), contaminated soils, and structures and equipment contaminated with waste, and manage them as hazardous waste, unless $\$ 261.3(d)$ of this Chapter (CFR Title 40) applies. The closure plan, closure activities, cost estimates for closure, and financial responsibility for the tank systems must meet all of the requirements specified in subparts $\mathrm{G}$ and $\mathrm{H}$ of this part (IDAPA 58.01.05.008 [40 CFR 264.197(a)]).

This closure performance standard will be achieved as follows:

- $\quad$ Residual hazardous waste inventory will be removed and managed as specified in Subsection 5.1

- $\quad$ Tank system lines and equipment undergoing HWMA/RCRA closure will be removed and managed as specified in Subsection 5.2.

- $\quad$ The direct buried lines and soils beneath CPP-602 and the waste trench will be managed as part of CERCLA Site CPP-117. The stainless steel lines beneath the building will be rinsed to the extent practicable. Both the stainless steel and the cast iron lines will be isolated and sealed where they enter and exit the accessible CPP-602 basement area. Hazardous contaminants will be removed from the waste trench to the extent practicable by rinsing or mopping. 


\section{CLOSURE ACTIVITIES}

This closure plan describes the methods for closing the CPP-602 laboratory lines per the tank system closure performance standard requirements of IDAPA 58.01.05.008 (40 CFR 264, Subparts G and J). The closure approach of the CPP-602 laboratory lines is removal of the HWMA/RCRA contamination and components to the extent practicable. The following subsections describe closure activities, waste management activities, and required closure documentation to satisfy the tank system closure performance standards.

\subsection{Removal Activities}

The removal activities consist primarily of three major steps:

1. Removing residual liquids and solids remaining in hold up areas of waste lines

2. Rinsing buried waste lines and waste trench to remove contamination to the extent practicable

3. Removing waste lines.

\subsubsection{Removing Residual Liquids and Solids}

Specific locations within the waste lines, such as in P-traps below laboratory sinks, that may have retained residual liquid or solids will be removed and sent to a permitted TSDF (see Section 5.2.1).

\subsubsection{Rinsing Buried Waste Lines and Waste Trench}

The intact stainless steel lines buried beneath the basement floor will be flushed to remove contamination to the extent practicable. The waste trench also will be rinsed or mopped to remove contamination to the extent practical. The decontamination solutions generated during these activities will be sent to a permitted TSDF for treatment or disposal or both. The buried lines (including both the intact stainless steel lines and the nonintact cast iron lines) and the waste trench are part of CERCLA Site CPP-117, will not be removed from the basement structure, and are not subject to any further closure requirements. These lines will be physically isolated to ensure that material cannot re-enter that part of the closed system.

\subsubsection{Removing Waste Lines}

Most of the lines identified in this closure plan and shown in Figure 1 have been rinsed and sampled. The sample data will be compared to waste management levels (addressed in Subsection 5.2.2) to determine appropriate waste management. With the exception of the lines buried beneath the basement floor, these lines will be removed and managed as specified in Subsection 5.2.2.

\subsection{Waste Management}

As required by IDAPA 58.01.05.008 (40 CFR 264.114), contaminated equipment and structures must be properly disposed of or decontaminated in accordance with applicable requirements. Waste generated during closure activities may include nonhazardous industrial waste, nonhazardous liquid waste, HWMA/RCRA hazardous waste, and mixed waste.

Waste generated from the D\&D of Building CPP-602, including closure-derived waste, will be managed in compliance with the substantive requirements for generators (IDAPA 58.01.05.006 [40 CFR 262]) as part of the CERCLA non-time critical removal action. All waste will undergo a 
hazardous waste determination, and waste profiles will be prepared for each waste grouping that will document the decision process for waste management. Because the lines in the system undergoing closure conveyed listed hazardous waste, closure-derived waste that came in direct contact with the waste from the inside of the lines system will have the F001, F002, F003, F005, and U134 listed codes attached in addition to any applicable characteristic codes.

\subsubsection{Waste Removed from the Tank System Components}

Waste removed from the tank system (such as might be found in P-traps) during removal of components under closure or during decontamination activities will be sent to a permitted TSDF for appropriate treatment or disposal or both.

\subsubsection{Regulated Lines Subject to Waste Management Level Determination}

The CPP-602 laboratory lines will be closed under HWMA/RCRA by removal in coordination with the D\&D of Building CPP-602 as part of the CERCLA non-time critical removal action (DOE-ID 2009a). Most of the HWMA/RCRA-regulated lines have been subject to iterative decontamination and sampling. All lines above the basement floor will be removed. Those lines where the concentration of contaminants of concern comply with the waste management levels established in Table 2 will be disposed of in a CERCLA-approved landfill, such as the Idaho CERCLA Disposal Facility. Those lines where compliance with the waste management levels cannot be demonstrated will be sent off the INL Site to a TSDF for appropriate treatment or disposal or both.

The final rinsate solution from each decontamination was collected directly from the waste lines just before it left Building CPP-602. The system components undergoing decontamination and the sample locations were recorded, and documentation will be provided to the PE for the closure certification. The final rinsate solutions from decontamination were collected in accordance with the "Sampling Procedure for HWMA/RCRA Closure of the CPP-601 Deep Tanks System" (SPR-185). A data quality assessment of the data will be prepared documenting those line sections that comply or do not comply with the waste management levels. This data quality assessment will be provided to the PE and DEQ.

The contaminants of concern were identified based on those identified in the following:

- $\quad$ Closure Plan for the CPP-641 Westside Waste Holdup Tanks System (DOE-ID 2008a)

- $\quad H W M A / R C R A$ Closure Plan for the CPP-601 Waste Transfer Lines to the Tank Farm Facility (DOE-ID 2008b)

- $\quad$ Partial Permit for HWMA Storage and Treatment for the Liquid Waste Management System at the Idaho Nuclear Technology and Engineering Center on the Idaho National Laboratory (State of Idaho 2008)

- $\quad$ A Regulatory Analysis and Reassessment of U.S. Environmental Protection Agency Listed Hazardous Waste Numbers for Applicability to the INTEC Liquid Waste System (INEEL 1999)

- HWMA/RCRA Landfill Closure Plan for the CPP-601 Deep Tanks System-Phase 1 (DOE-ID 2009b).

The waste management levels identified in Table 2 are set at the same risk-based levels as were established for clean closure of other parts of the INTEC liquid waste management system. This closure plan uses compliance with these risk-based levels to demonstrate that hazardous constituents in the lines have been sufficiently removed to meet closure requirements. Because of the wide nature of contaminants of concern (metals, semivolatile organic compounds, and volatile organic compounds), final rinsate 
samples were analyzed for EPA Contract Laboratory Program metals, semivolatile organic compounds using EPA SW-846 Method 8270C (or equivalent), volatile organic compounds using EPA SW-846 Method 8260B (or equivalent), and hydrogen fluoride using EPA SW-846 Method 9056 (or equivalent) (EPA 2007).

Table 2. Contaminants of concern and corresponding waste management levels.

\begin{tabular}{|c|c|c|c|}
\hline Contaminant of Concern & $\begin{array}{c}\text { Waste Management } \\
\text { Level } \\
(\mathrm{mg} / \mathrm{L} \text { rinsate })\end{array}$ & Contaminant of Concern & $\begin{array}{c}\text { Waste Management } \\
\text { Level } \\
(\mathrm{mg} / \mathrm{L} \text { rinsate })\end{array}$ \\
\hline Antimony & $2.8 \mathrm{E}+01$ & Chloromethane & $2.8 \mathrm{E}+01$ \\
\hline Arsenic & $6.1 \mathrm{E}-01$ & Cresol & $2.8 \mathrm{E}+01$ \\
\hline Barium & $2.8 \mathrm{E}+01$ & Cyclohexanone & $2.8 \mathrm{E}+01$ \\
\hline Beryllium & $2.8 \mathrm{E}+01$ & 1,2-Dichloroethane & $3.0 \mathrm{E}-01$ \\
\hline Cadmium & $6.0 \mathrm{E}-01$ & Ethyl acetate & $2.8 \mathrm{E}+01$ \\
\hline Chromium & $3.0 \mathrm{E}+00$ & Ethylbenzene & $2.8 \mathrm{E}+01$ \\
\hline Lead & $3.0 \mathrm{E}+00$ & Hexachlorobenzene & $7.8 \mathrm{E}-02$ \\
\hline Mercury & $1.2 \mathrm{E}-01$ & Hexachloroethane & $6.1 \mathrm{E}-01$ \\
\hline Nickel & $2.8 \mathrm{E}+01$ & Hydrogen Fluoride & $2.8 \mathrm{E}+01$ \\
\hline Selenium & $6.0 \mathrm{E}-01$ & Methanol & $2.8 \mathrm{E}+01$ \\
\hline Silver & $3.0 \mathrm{E}+00$ & 4-Methyl-2-Pentanone & $2.8 \mathrm{E}+01$ \\
\hline Thallium & $2.8 \mathrm{E}+01$ & Methylene chloride & $6.1 \mathrm{E}-01$ \\
\hline Vanadium & $2.8 \mathrm{E}+01$ & n-nitro-di-n-butylamine & $5.8 \mathrm{E}-02$ \\
\hline Zinc & $2.8 \mathrm{E}+01$ & Nitrobenzene & $1.2 \mathrm{E}+00$ \\
\hline Acetone & $2.8 \mathrm{E}+01$ & Phenol & $2.8 \mathrm{E}+01$ \\
\hline Benzene & $3.0 \mathrm{E}-01$ & Pyridine & $3.0 \mathrm{E}+00$ \\
\hline Bis(2-ethylhexyl) phthalate & $6.1 \mathrm{E}-01$ & Tetrachloroethylene & $4.2 \mathrm{E}-01$ \\
\hline Bromomethane & $1.3 \mathrm{E}+01$ & Toluene & $2.8 \mathrm{E}+01$ \\
\hline 2-Butanone (MEK) & $2.8 \mathrm{E}+01$ & 1,1,1-Trichloroethane & $2.8 \mathrm{E}+01$ \\
\hline Carbon disulfide & $2.8 \mathrm{E}+01$ & Trichlorofluoromethane & $2.8 \mathrm{E}+01$ \\
\hline Carbon tetrachloride & $3.0 \mathrm{E}-01$ & Trichloroethylene & $3.0 \mathrm{E}-01$ \\
\hline Chlorobenzene & $2.8 \mathrm{E}+01$ & Xylenes & $2.8 \mathrm{E}+01$ \\
\hline Chloroform & $3.6 \mathrm{E}+00$ & Aroclor-1260 & $6.1 \mathrm{E}-01$ \\
\hline
\end{tabular}




\subsubsection{Other Waste}

All other waste generated during the D\&D of Building CPP-602 as a CERCLA non-time critical removal action (including all other closure-derived waste, such as secondary containment systems without visible contamination) will be sent to an appropriate CERCLA disposal facility, such as the Idaho CERCLA Disposal Facility, for disposal. The D\&D of the building is expected to generate some industrial waste that has not come in contact with either radioactive or hazardous constituents. Such waste may be sent to CERCLA-approved industrial landfills.

\subsection{Closure Documentation}

Closure methods and attainment of the closure performance standards for units and components being HWMA/RCRA-closed will be documented as follows:

- Closure activities will be monitored and reviewed by a qualified PE. Following successful completion of closure activities, the PE will certify that the closure was performed in accordance with the DEQ-approved closure plan.

- Information related to successful implementation of closure will be recorded or documented, and provided to the PE, as requested, to support closure certification. Successful demonstration of achieving closure performance standards may include, but is not limited to, the following:

- $\quad$ Documentation of decontamination activities specified in this closure plan, including procedures, work orders, validated sampling data, and data quality assessment reports, as appropriate

- $\quad$ Documentation of removal activities specified in this closure plan, including procedures, and work orders, as appropriate

- $\quad$ System isolation records

- $\quad$ Closure-derived waste management records. 


\section{CLOSURE SCHEDULE}

Table 3 identifies the closure schedule that will be initiated following DEQ approval of this closure plan. This schedule reflects the time required for conducting closure activities and submitting information to the PE for certification. IDAPA 58.01.05.008 (40 CFR 264.113) requires waste removal activities be completed 90 days from the approval of the closure plan and closure be completed within 180 days from the initiation of closure activities. An extension to these periods is being requested, pursuant to IDAPA 58.01.05.008 (40 CFR 264.113), to ensure that data of adequate quality are collected to show compliance with the waste management levels. An extension is requested for the 180-day closure period to protect human health and the environment and to adequately perform closure activities. Waste removal, decontamination, and closure activities cannot be completed within the required timeframes due to several factors including, but not limited to, the following:

- $\quad$ The need to provide radiological contamination controls to prevent the possible spread of contamination

- All work related to management of radioactive mixed waste requires additional time due to the work planning requirements, including radiological work permits

- $\quad$ The time necessary for the analytical laboratories to analyze samples and validate data, receive analytical results, and complete data quality assessment, as necessary to support appropriate waste characterization, management, and disposition

- $\quad$ Complexities of accessing and removing lines from the entire building due to the radiological environment.

Quarterly reports summarizing closure activity progress will be submitted to DEQ by April 30, July 31, October 31, and January 31 of each year commencing with the first quarter after approval of the closure plan.

Table 3. CPP-602 laboratory lines closure schedule.

\begin{tabular}{ll}
\multicolumn{1}{c}{ Activity } & Completion \\
\hline $\begin{array}{l}\text { Idaho Department of Environmental Quality approval of closure plan } \\
\begin{array}{l}\text { Cessation of all laboratory related activities and initiation of decontamination and } \\
\text { decommissioning within CPP-602 }\end{array}\end{array}$ & Day 0 \\
Submittal of data quality assessment for lines compared to waste management levels & Day 120 \\
Complete removal of all CPP-602 hazardous waste lines above ground level & Day 180 \\
$\begin{array}{l}\text { Complete removal of all CPP-602 hazardous waste lines above basement floor } \\
\text { Complete decontamination of direct buried lines and waste trench }\end{array}$ & Day 270 \\
$\begin{array}{l}\text { Complete waste management activities } \\
\text { Complete closure activities }\end{array}$ & Day 365 \\
$\begin{array}{l}\text { Submit professional engineer and owner/operator certification to Idaho Department of } \\
\text { Environmental Quality within } 60 \text { days of completion of closure }\end{array}$ & Day 490 \\
\hline $\begin{array}{l}\text { a. If closure activities are completed ahead of the proposed schedule, the Department of Energy will submit the closure } \\
\text { certification to the Idaho Department of Environmental Quality within 60 days of completion of closure activities. }\end{array}$ \\
\hline
\end{tabular}




\section{CLOSURE PLAN AMENDMENTS}

The conditions described in IDAPA 58.01.05.008 (40 CFR 264.112), "Closure Plan; Amendment of Plan," will be followed to implement changes to the approved closure plan. If unexpected events during the closure period require modifying the approved closure activities or closure schedule, the closure plan will be amended, or DEQ will be otherwise notified within 30 days of the unexpected event. A written request detailing the proposed changes and the rationale for those changes, and a copy of the amended closure plan will be submitted to DEQ for approval, or DEQ will be otherwise notified. Minor deviations from the approved closure plan, which are equivalent to or do not compromise the closure requirements and performance standards identified in the approved closure plan, may be made without prior notification to DEQ. Minor deviations will be identified in the documentation supporting the PE certification. 


\section{CERTIFICATION OF CLOSURE}

Within 60 days of completing the closure activities, a certification of closure of the CPP-602 laboratory lines will be completed, in accordance with IDAPA 58.01.05.008 (40 CFR 264.115), by a qualified PE and the U.S. Department of Energy Idaho Operations Office. The PE and owner/operator signatures on the closure certification, which is submitted to DEQ, will document the completion of closure activities in accordance with the approved closure plan and State of Idaho HWMA/RCRA requirements. The closure certification also may identify any minor changes to the closure plan without prior approval of DEQ. Closure of the CPP-602 laboratory lines will be considered complete upon receipt

of written acceptance issued by DEQ. The CPP-602 laboratory lines are not a hazardous waste disposal facility and, therefore, a "Notice in Deed" and a survey plat are not required. 


\section{COST AND LIABILITY REQUIREMENTS}

The federal government, as owner of the INL Site, is exempt from the requirements to provide cost estimates for closure, to provide a financial assurance mechanism for closure, and regarding state-required mechanism and state assumption of responsibility per IDAPA 58.01.05.008

[40 CFR 264.140(c)]. The federal government, as owner of the INL Site, is also exempt from liability requirements. 


\section{REFERENCES}

40 CFR 261, 2009, "Identification and Listing of Hazardous Waste," Code of Federal Regulations, Office of the Federal Register.

40 CFR 262, 2009, "Standards Applicable to Generators of Hazardous Waste," Code of Federal Regulations, Office of the Federal Register.

40 CFR 264, 2008, "Standards for Owners and Operators of Hazardous Waste Treatment, Storage, and Disposal Facilities," Code of Federal Regulations, Office of the Federal Register.

40 CFR 264.111, 2008, "Closure Performance Standard," Code of Federal Regulations, Office of the Federal Register.

40 CFR 264.112, 2008, "Closure Plan; Amendment of Plan," Code of Federal Regulations, Office of the Federal Register.

40 CFR 264.113, 2008, "Closure; Time Allowed for Closure," Code of Federal Regulations, Office of the Federal Register.

40 CFR 264.114, 2008, "Disposal or Decontamination of Equipment, Structures, and Soils," Code of Federal Regulations, Office of the Federal Register.

40 CFR 264.115, 2008, "Certification of Closure," Code of Federal Regulations, Office of the Federal Register.

40 CFR 264.140, 2008, "Applicability," Code of Federal Regulations, Office of the Federal Register.

40 CFR 264.197 2008, "Closure and Post-Closure Care," Code of Federal Regulations, Office of the Federal Register.

42 USC $§ 6901$ et seq., 1976, "Resource Conservation and Recovery Act of 1976," United States Code.

DOE-ID, 2000, Operable Unit 3-13 Group 2 Closure Evaluation Criteria and Checklist, DOE/ID-10775, Rev. 1, U.S. Department of Energy Idaho Operations Office.

DOE-ID, 2007, Record of Decision for Tank Farm Soil and INTEC Groundwater, Operable Unit 3-14, DOE/ID-11296, U.S. Department of Energy, Idaho Operations Office.

DOE-ID, 2008a, Closure Plan for the CPP-641 Westside Waste Holdup Tanks System, DOE/ID-11341, Rev. 2, U.S. Department of Energy Idaho Operations Office.

DOE-ID, 2008b, HWMA/RCRA Closure Plan for the CPP-601 Waste Transfer Lines to the Tank Farm Facility, Voluntary Consent Order SITE-TANK-005 Action Plan, Tank System INTEC-601, Rev. 0, DOE/ID-11325, U.S. Department of Energy Idaho Operations Office.

DOE-ID, 2009a, Action Memorandum for General Decommissioning Activities under the Idaho Cleanup Project, DOE/ID-11293, Rev. 1, U.S. Department of Energy Idaho Operations Office.

DOE-ID, 2009b, HWMA/RCRA Landfill Closure Plan for the CPP-601 Deep Tanks System-Phase 1, DOE/ID-11376, Rev. 2, U.S. Department of Energy Idaho Operations Office.

EPA, 2007, Test Methods for Evaluating Solid Waste: Physical/Chemical Methods, SW-846, ${ }^{\text {rd }}$ Edition, U.S. Environmental Protection Agency, Office of Solid Waste and Emergency Response, http://www.epa.gov/epaoswer/hazwaste/test/main.htm, Web page updated December 3, 2008, Web page visited August 6, 2008. 
Idaho Code § 39-4401 et seq., 1983, "Hazardous Waste Management Act of 1983," State of Idaho, Boise, Idaho.

IDAPA 58.01.05.006, 2009, "Standards Applicable to Generators of Hazardous Waste," Idaho Administrative Procedures Act, Idaho Department of Environmental Quality.

IDAPA 58.01.05.008, 2009, "Standards for Owners and Operators of Hazardous Waste Treatment, Storage, and Disposal Facilities," Idaho Administrative Procedures Act, Idaho Department of Environmental Quality Rules, as amended.

INEEL, 1999, A Regulatory Analysis \& Reassessment of U.S. Environmental Protection Agency (EPA) Listed Hazardous Waste Numbers for Applicability to the INTEC Liquid Waste System - WAG-3, INEEL/EXT-98-01213, Rev. 1, Idaho National Engineering and Environmental Laboratory.

SPR-185, 2009, "Sampling Procedure for the HWMA/RCRA Closure of the CPP-601 Deep Tanks System," Rev. 2, Idaho Cleanup Project.

State of Idaho, 2008, Partial Permit for HWMA Storage and Treatment for the Liquid Waste Management System at the Idaho Nuclear Technology and Engineering Center on the Idaho National Laboratory, EPA ID No. ID4890008952 (PER-111), Effective Date: October 18, 2004, Revision Date: October 29, 2008. 


\section{Appendix A \\ CPP-602 System Components and Boundaries}




\section{Appendix A \\ CPP-602 System Components and Boundaries}

Table A-1. CPP-602 system boundaries.

\begin{tabular}{|c|c|c|c|}
\hline Lines & Start Point & End Point & Comments \\
\hline \multicolumn{4}{|c|}{ GROUP 1 - RINSED } \\
\hline \multicolumn{4}{|c|}{ Lab 211 North Middle Bench } \\
\hline 2" LB-1097T & $211 \mathrm{~W} 2$, and $212 \mathrm{~W} 1$ & 2" LB-1096C & \\
\hline 2" LB-1096C & 2" LB-1097T & 3" LD-1115C & \\
\hline $211 \mathrm{~W} 2$ & Wash sink & 2" LB-1097T & \\
\hline 211D1 & Hood D drain \#1 & 2" LB-1097T & \\
\hline $211 \mathrm{D} 2$ & Hood D drain \#2 & 2" LB-1097T & \\
\hline $211 \mathrm{E} 1$ & Hood E drain \#1 & 2" LB-1097T & \\
\hline $211 \mathrm{E} 2$ & Hood E drain \#2 & 2" LB-1097T & \\
\hline \multicolumn{4}{|c|}{ Lab 212 Center Bench } \\
\hline $212 \mathrm{~W} 1$ & Wash sink & 2" LB-1097T & \\
\hline \multicolumn{4}{|c|}{ Lab 211 South Middle Bench } \\
\hline $211 \mathrm{~A}$ & Hood A & 2" LB-1099C & \\
\hline $211 \mathrm{~B}$ & Hood B & 2" LB-1099C & \\
\hline $211 \mathrm{C}$ & Hood C & 2" LB-1099C & \\
\hline $211 \mathrm{~F}$ & Hood F & 2" LB-1099C & \\
\hline $211 \mathrm{G}$ & Hood G & 2" LB-1099C & \\
\hline $211 \mathrm{H}$ & Hood H & 2" LB-1099C & \\
\hline 2" LB-1099C & $211 \mathrm{C}$, and $211 \mathrm{~F}$ & 3" LB-1103C & \\
\hline 3" LB-1103C & 2" LB-1102C & 3" LD-1115C & \\
\hline 2" LB-1102C & Cap inside Chase \#7 & 3" LB-1103C & \\
\hline \multicolumn{4}{|c|}{ Lab 211 South Bench } \\
\hline $211 \mathrm{C} 1$ & Cup sink & 2" LB-1106C & \\
\hline $211 \mathrm{~W} 1$ & Wash sink & 2" LB-1106C & \\
\hline \multicolumn{4}{|c|}{ Lab 208 South Bench } \\
\hline $208 \mathrm{~A}$ & Hood A & 2" LB-1106C & \\
\hline 208B & Hood B & 2" LB-1106C & \\
\hline
\end{tabular}


Table A-1. (continued).

\begin{tabular}{|l|l|l|l|}
\hline \multicolumn{1}{|c|}{ Lines } & \multicolumn{1}{|c|}{ Start Point } & \multicolumn{1}{c|}{ End Point } & \multicolumn{1}{c|}{ Comments } \\
\hline 2" LB-1106C & 211C1, and 208B & 2" LB-1105C & $\begin{array}{l}\text { Includes cap from } \\
\text { air gap in the glove } \\
\text { box drain }\end{array}$ \\
\hline 2" LB-1105C & 2" LB-1106C & 3" LD-1115C & \\
\hline Lab 207 North Bench & Hood D & 2" LB-1104C & \\
\hline 207D & Hood C & 2" LB-1104C & Includes cap behind \\
207C & 207D & 2" LB-1106C & \\
\hline 2" LB-1104C & & 2" LB-1107C & \\
\hline Lab 204 North bench
\end{tabular}

GROUP 2 - RINSED

Lab 214

\begin{tabular}{|l|l|l|l}
\hline Unlabeled $^{\text {a } 3 C}$ & Wash sink & Unlabeled $^{\text {a } 3 A}$ & \\
\hline
\end{tabular}

Lab 224

\begin{tabular}{|l|l|l|l|}
\hline Unlabeled $^{\text {a } 3 B}$ & Wash sink & Unlabeled $^{\text {a } 3 A}$ & \\
\hline Unlabeled $^{\text {a } 3 \mathrm{~A}}$ & Unlabeled $^{\mathrm{a}}$ 3B & 4" LD-1039C & \\
\hline
\end{tabular}

Lab 227 South Middle Bench and North Middle Bench

\begin{tabular}{|l|l|l|l|}
\hline $227 \mathrm{~W} 1$ & Wash sink & 2" LB-1005C & \\
\hline $227 \mathrm{CS} 1$ & Cup sink & 2" LB-1005C & \\
\hline 2" LB-1005C & $227 \mathrm{~W} 1$ & 2" LB-1014C & $\begin{array}{l}\text { Includes capped } \\
\text { drain PEW-220-3 }\end{array}$ \\
\hline 2" LB-1045T & Capped floor Drain \#2 & 2" LB-1046T & \\
\hline 227W2 & wash sink & 2" LB-1008C & \\
\hline 2" LB-1008C & $227 \mathrm{~W} 2$ & 2" LB-1046T & $\begin{array}{l}\text { Includes capped } \\
\text { drain PEW-220-2 }\end{array}$ \\
\hline 2" LB-1044T & Capped floor Drain \#3 & 2" LB-1046T & \\
\hline 2" LB-1046T & Capped floor Drain \#1 & 3" LB-1004T & \\
\hline
\end{tabular}


Table A-1. (continued).

\begin{tabular}{|c|c|c|c|}
\hline Lines & Start Point & End Point & Comments \\
\hline \multicolumn{4}{|l|}{ Lab 223/216 } \\
\hline 2" LB-1043T & Capped floor Drain \#4 & 2" LB-1014C & \\
\hline 2" LB-1014C & 2" LB-1005C & 4" LB-1049C & \\
\hline 4" LB-1049C & 2" LB-1014C & 4" LD-1039C & \\
\hline Unlabeled $^{\text {a } 3 F}$ & Cap in Chase \#4 & 2" LB-1014C & \\
\hline \multicolumn{4}{|c|}{ Lab 211 North Bench } \\
\hline $211 \mathrm{C} 2$ & Cup sink & 2" LB-1009C & \\
\hline \multicolumn{4}{|c|}{ Lab 212 North Bench } \\
\hline $212 \mathrm{~A}$ & Hood A & 2" LB-1009C & \\
\hline 212B & Hood B & 2" LB-1009C & \\
\hline 2" LB-1009C & $212 \mathrm{~B}$, and $211 \mathrm{C} 2$ & 3" LB-1050C & $\begin{array}{l}\text { Includes capped line } \\
\text { in } \mathrm{Lab} 216\end{array}$ \\
\hline 3" LB-1050C & 2" LB-1009C & 4" LD-1039C & \\
\hline 2" LB-1048C & Cap in Chase \#6 & 3" LB-1050C & \\
\hline 2" LB-1041T & Capped floor Drain \#5 & 3" LB-1050C & \\
\hline \multicolumn{4}{|l|}{ Lab 327} \\
\hline Unlabeled $^{\mathrm{a}} 4 \mathrm{~A}$ & Wash sink & 3" LB-1004T & \\
\hline Unlabeled $^{\mathrm{a}} 4 \mathrm{C}$ & Hood A & Unlabeled $^{\mathrm{a}} 4 \mathrm{~B}$ & \\
\hline 3" LB-1004T & Unlabeled $^{\mathrm{a}} 4 \mathrm{~A}$ & 4" LD-1039C & \\
\hline \multicolumn{4}{|l|}{ Lab 325} \\
\hline Unlabeled $^{\mathrm{a}}$ 4D & North wash sink & Unlabeled $^{\mathrm{a}} 4 \mathrm{E}$ & \\
\hline Unlabeled $^{\mathrm{a}} 4 \mathrm{E}$ & Unlabeled $^{\mathrm{a}} 4 \mathrm{D}$ & Unlabeled $^{\mathrm{a}} 4 \mathrm{~B}$ & \\
\hline Unlabeled $^{\mathrm{a}}$ 4B & Unlabeled $^{\mathrm{a}} 4 \mathrm{G}$ & 3" LD-1091C & \\
\hline $325 \mathrm{~B}$ & Hood B & Unlabeled $^{\mathrm{a}} 4 \mathrm{D}$ & \\
\hline $325 \mathrm{~A}$ & Hood A & Unlabeled $^{\mathrm{a}} 4 \mathrm{~F}$ & \\
\hline Unlabeled $^{\mathrm{a}} 4 \mathrm{~F}$ & South wash sink & Unlabeled $^{\mathrm{a}} 4 \mathrm{G}$ & \\
\hline Unlabeled $^{\mathrm{a}} 4 \mathrm{G}$ & Unlabeled $^{\mathrm{a}} 4 \mathrm{~F}$ & Unlabeled $^{\mathrm{a}} 4 \mathrm{~B}$ & \\
\hline 3" LD-1091C & Unlabeled $^{\mathrm{a}} 4 \mathrm{~B}$ & 3" LD-1115C & \\
\hline
\end{tabular}

\section{GROUP 3 - RINSED}

\section{Lab 213}

\begin{tabular}{|l|l|l|l|}
\hline 2" LB-11056 & Wash sink & 3" LB-1055C & \\
\hline 3" LB-1055C & 2" LB-11056 & 3" LB-1029C & \\
\hline
\end{tabular}


Table A-1. (continued).

\begin{tabular}{|c|c|c|c|}
\hline Lines & Start Point & End Point & Comments \\
\hline \multicolumn{4}{|c|}{ Lab 207 South Bench } \\
\hline $207 \mathrm{~A}$ & Hood A & 2" LB-1055C & \\
\hline 207B & Hood B & 2" LB-1055C & \\
\hline 2" LB-1055C & 207A, and $204 \mathrm{~B}$ & 3" LB-1054C & \\
\hline 3" LB-1054C & 2" LB-1030C & 4" LD-1039C & \\
\hline 2" LB-1037T & Capped floor Drain \#9 & 2" LB-1030C & \\
\hline \multicolumn{4}{|c|}{ Lab 204 South Bench } \\
\hline $204 \mathrm{~A}$ & Hood A & 2" LB-1055C & \\
\hline 204B & Hood B & 2" LB-1055C & \\
\hline 2" LB-1112C & Cap behind south bench & 3" LB-1110C & \\
\hline 3" LB-1110C & 2" LB-1108C & 3" LD-1115C & \\
\hline \multicolumn{4}{|c|}{ Lab 207 Center Bench } \\
\hline $207 \mathrm{~W} 1$ & East wash sink & 2" LB-1030C & \\
\hline $207 \mathrm{~W} 2$ & West wash sink & $207 \mathrm{~W} 1$ & \\
\hline \multicolumn{4}{|c|}{ Lab 204 Center Bench } \\
\hline $204 \mathrm{~W} 1$ & East wash sink & 2" LB-1030C & \\
\hline $204 \mathrm{~W} 2$ & West wash sink & $204 \mathrm{~W} 1$ & \\
\hline 2" LB-1108C & Cap in Chase \#10 & 3" LB-1110C & \\
\hline 2" LB-1038T & Capped floor Drain \#8 & 3" LB-1053C & \\
\hline 3" LB-1053C & 2" LB-1025C & 4" LD-1039C & \\
\hline 2" LB-1025C & Cap in Chase \#9 & 3" LB-1053C & \\
\hline 2" LB-1024C & Cap in Chase \#9 & 3" LB-1052C & \\
\hline 3" LB-1052C & 2" LB-1018C & 4" LD-1039C & \\
\hline 2" LB-1030C & 204W1, AND 207W1 & 3" LB-1054C & \\
\hline \multicolumn{4}{|c|}{ Lab 208 Center Bench } \\
\hline 2" LB-1019C & Wash sink & 2" LB-1020C & \\
\hline 2" LB-1020C & 2" LB-1019C & 2" LB-1018C & \\
\hline 2" LB-1018C & 2" LB-1020C & 3" LB-1029C & $\begin{array}{l}\text { Includes cap from } \\
\text { Lab } 211 \text { south } \\
\text { middle bench }\end{array}$ \\
\hline 2" LB-1039T & Capped floor Drain \#7 & 3" LB-1029C & \\
\hline 3" LB-1029C & 2" LB-1018C & 3" LB-1052C & \\
\hline
\end{tabular}


Table A-1. (continued).

\begin{tabular}{|c|c|c|c|}
\hline Lines & Start Point & End Point & Comments \\
\hline \multicolumn{4}{|c|}{ Lab 211 Center Bench } \\
\hline 2" LB-1015C & Wash sink & 3" LB-1051C & \\
\hline 2" LB-1016C & Cup sink & 2" LB-1015C & \\
\hline 3" LB-1051C & 2" LB-1015C & 4" LD-1039C & $\begin{array}{l}\text { Includes cap inside } \\
\text { Chase } \# 7\end{array}$ \\
\hline 2" LB-1040T & Capped floor Drain \#6 & 3" LB-1051C & \\
\hline Unlabeled $^{\mathrm{a}} 3 \mathrm{G}$ & Cap inside Chase \#7 & 3" LB-1051C & \\
\hline \multicolumn{4}{|l|}{ GROUP 4 - RINSED } \\
\hline \multicolumn{4}{|l|}{ Lab 103} \\
\hline 3/4" PE-AR-151826 & Hood \#1 Drain & 1" PE-AR-151826 & \\
\hline 1" PE-AR-151826 & 3/4" PE-AR-151826 & 1 1/2" PE-AR-151826 & \\
\hline $11 / 2$ PE-AR-151826 & 1" PE-AR-151826 & 2" PE-AR-151826 & \\
\hline 2" PE-AR-151826 & $11 / 2$ " PE-AR-151826 & 2" LC-1085C & $\begin{array}{l}\text { Includes cap from } \\
\text { air gap in the } \\
\text { Shielded Cave drain }\end{array}$ \\
\hline 2" LC-1085C & 2" PE-AR-151826 & 4" LD-1039C & \\
\hline 1" PE-AR-151888 & Wash Sink \#4 drain & 1" PE-AR-151826 & \\
\hline 3/4" PE-AR-151896 & Hood \#2 drain & 1" PE-AR-151888 & \\
\hline 3/4" PE-AR-151895 & Hood \#3 drain & 1" PE-AR-151888 & \\
\hline 1" PE-AR-151889 & Wash Sink \#3 drain & 1 1/2" PE-AR-151826 & \\
\hline 3/4" PE-AR-151792 & Hood \#4 drain & 1" PE-AR-151889 & \\
\hline 3/4" PE-AR-151791 & Hood \#5 drain & 1" PE-AR-151889 & \\
\hline 1" PE-AR-151891 & Wash Sink \#2 & 2" PE-AR-151826 & \\
\hline 3/4" PE-AR-151801 & Hood \#6 drain & 1" PE-AR-151891 & \\
\hline 3/4" PE-AR-151795 & Hood \#7 drain & 1" PE-AR-151891 & \\
\hline 1" PE-AR-151892 & Wash Sink \#1 drain & 2" PE-AR-151826 & \\
\hline 3/4" PE-AR-151851 & Hood \#8 drain & 1" PE-AR-151892 & \\
\hline 3/4" PE-AR-151850 & Hood \#9 drain & 1" PE-AR-151892 & \\
\hline Unlabeled $^{\mathrm{a}}$ 1I & Cave drain & 2" PE-AR-151826 & \\
\hline \multicolumn{4}{|l|}{ Lab 224} \\
\hline 1" LD-O-1115C & $\begin{array}{l}\text { Spec. Cave drain above } \\
\& \text { below air gap }\end{array}$ & 3" LD-1115C & \\
\hline
\end{tabular}


Table A-1. (continued).

\begin{tabular}{|c|c|c|c|}
\hline Lines & Start Point & End Point & Comments \\
\hline \multicolumn{4}{|l|}{ Lab 227 North Bench } \\
\hline $227 \mathrm{C} 1$ & Hood C Drain \#1 & Unlabeled $^{\mathrm{a}} 3 \mathrm{D}$ & \\
\hline $227 \mathrm{C} 2$ & Hood C Drain \#2 & Unlabeled $^{\mathrm{a}} 3 \mathrm{D}$ & \\
\hline $227 \mathrm{CS} 2$ & Cup sink & Unlabeled $^{\mathrm{a}} 3 \mathrm{D}$ & \\
\hline Unlabeled $^{\mathrm{a}} 3 \mathrm{D}$ & $227 \mathrm{C} 1$ & 3" LD-1091C & $\begin{array}{l}\text { Includes capped } \\
\text { drain PEW-220-1 }\end{array}$ \\
\hline \multicolumn{4}{|l|}{ Lab 220 South Bench } \\
\hline PEW-220-4 & Cap on west wall & Unlabeled $^{\mathrm{a}} 3 \mathrm{E}$ & \\
\hline $220 \mathrm{~W}$ & Wash sink & Unlabeled $^{\mathrm{a}} 3 \mathrm{E}$ & \\
\hline \multicolumn{4}{|l|}{ Lab 227 South Bench } \\
\hline $227 \mathrm{~A}$ & Hood A & Unlabeled $^{\mathrm{a}} 3 \mathrm{E}$ & \\
\hline $227 \mathrm{~B}$ & Hood B & Unlabeled $^{\mathrm{a}} 3 \mathrm{E}$ & \\
\hline Unlabeled $^{\mathrm{a}} 3 \mathrm{E}$ & 227B, and PEW-220-4 & 3" LD-1091C & \\
\hline \multicolumn{4}{|l|}{ Waste Trench } \\
\hline 4" LD-1039C & $\begin{array}{l}\text { North end of east } \\
\text { header }\end{array}$ & 3" LD-1115C & \\
\hline 3" LD-1115C & $\begin{array}{l}\text { North end of west } \\
\text { header }\end{array}$ & LC-017 Sump & \\
\hline \multicolumn{4}{|c|}{ OTHER LINES ASSOCIATED WITH THIS CLOSURE THAT HAVE NOT BEEN RINSED } \\
\hline \multicolumn{4}{|l|}{ Waste Trench } \\
\hline 3" LD-1091C & Cleanout \#1 & 3" LD-1115C & \multirow{4}{*}{$\begin{array}{l}\text { These vertical waste } \\
\text { cleanout ports will } \\
\text { be removed and } \\
\text { shipped off the INL } \\
\text { Site for disposal as } \\
\text { hazardous waste }\end{array}$} \\
\hline 3" LD-1090C & Cleanout \#2 & 3"LD-1115C & \\
\hline 4" LB-1001C & Cleanout \#3 & 4" LD-1039C & \\
\hline 4" LB-1002C & Cleanout \#4 & 4" LD-1039C & \\
\hline \multicolumn{4}{|c|}{ Lab 103 - Buried Beneath Basement Floor } \\
\hline $\begin{array}{l}\text { Unlabeled }^{\text {a }} \text { Stainless } \\
\text { Steel 1A }\end{array}$ & $\begin{array}{l}\text { Unlabeled }^{\mathrm{a}} 1 \mathrm{~B} \text { and } \\
\text { Unlabeled }^{\mathrm{a}} 1 \mathrm{G}\end{array}$ & Unlabeled $^{\mathrm{a}} 1 \mathrm{H}$ & \multirow{4}{*}{$\begin{array}{l}\text { This stainless steel } \\
\text { lines will be triple- } \\
\text { rinsed and left in } \\
\text { place as part of } \\
\text { CERCLA Site CPP- } \\
117\end{array}$} \\
\hline $\begin{array}{l}\text { Unlabeled }^{\text {a }} \text { Stainless } \\
\text { Steel 1B }\end{array}$ & Cap under Hood \#1 & Unlabeled $^{\mathrm{a}} 1 \mathrm{~A}$ & \\
\hline $\begin{array}{l}\text { Unlabeled }^{\text {a }} \text { Stainless } \\
\text { Steel 1C }\end{array}$ & $\begin{array}{l}\text { Cap under Hood \#2 and } \\
\text { Hood \#3 bench }\end{array}$ & Unlabeled $^{\mathrm{a}} 1 \mathrm{~A}$ & \\
\hline $\begin{array}{l}\text { Unlabeled }^{\mathrm{a}} \text { Stainless } \\
\text { Steel 1D }\end{array}$ & $\begin{array}{l}\text { Cap under Hood \#4 and } \\
\text { Hood \#5 bench }\end{array}$ & Unlabeled $^{\mathrm{a}} 1 \mathrm{~A}$ & \\
\hline
\end{tabular}


Table A-1. (continued).

\begin{tabular}{|c|c|c|c|}
\hline Lines & Start Point & End Point & Comments \\
\hline $\begin{array}{l}\text { Unlabeled }^{\mathrm{a}} \text { Stainless } \\
\text { Steel 1E }\end{array}$ & $\begin{array}{l}\text { Cap under Hood \#6 and } \\
\text { Hood \#7 bench }\end{array}$ & Unlabeled $^{\mathrm{a}} 1 \mathrm{~A}$ & \\
\hline $\begin{array}{l}\text { Unlabeled }^{\text {a }} \text { Stainless } \\
\text { Steel } 1 \mathrm{~F}\end{array}$ & $\begin{array}{l}\text { Cap under Hood } \# 8 \text { and } \\
\text { Hood } \# 9 \text { bench }\end{array}$ & Unlabeled $^{\mathrm{a}} 1 \mathrm{~A}$ & \\
\hline $\begin{array}{l}\text { Unlabeled }^{\mathrm{a}} \text { Stainless } \\
\text { Steel } 1 \mathrm{G}\end{array}$ & $\begin{array}{l}\text { Cap under shielded } \\
\text { cave }\end{array}$ & Unlabeled $^{\mathrm{a}} 1 \mathrm{~A}$ & \\
\hline $\begin{array}{l}\text { Unlabeled }^{\mathrm{a}} \text { Stainless } \\
\text { Steel } 1 \mathrm{H}\end{array}$ & Unlabeled $^{\mathrm{a}} 1 \mathrm{~A}$ & 3" LD-1115C & \\
\hline $\begin{array}{l}\text { Unlabeled }{ }^{\mathrm{a}} \text { Cast Iron } \\
2 \mathrm{~A}\end{array}$ & $\begin{array}{l}\text { Unlabeled }^{\mathrm{a}} 2 \mathrm{~B} \text {, and } \\
\text { Unlabeled }^{\mathrm{a}} 2 \mathrm{G}\end{array}$ & Unlabeled $^{\mathrm{a}} 2 \mathrm{H}$ & \multirow{8}{*}{$\begin{array}{l}\text { This cast iron pipe is } \\
\text { no longer intact and } \\
\text { will not be rinsed. } \\
\text { The lines will be left } \\
\text { in place as part of } \\
\text { CERCLA Site } \\
\text { CPP-117. }\end{array}$} \\
\hline $\begin{array}{l}\text { Unlabeled }{ }^{\mathrm{a}} \text { Cast Iron } \\
\text { 2B }\end{array}$ & $\begin{array}{l}\text { Cap under Wash Sink } \\
\# 4\end{array}$ & Unlabeled $^{\mathrm{a}} 2 \mathrm{~A}$ & \\
\hline $\begin{array}{l}\text { Unlabeled }{ }^{\mathrm{a}} \text { Cast Iron } \\
2 \mathrm{C}\end{array}$ & $\begin{array}{l}\text { Capped Floor Drain } \\
\# 10\end{array}$ & Unlabeled $^{\mathrm{a}} 2 \mathrm{~A}$ & \\
\hline $\begin{array}{l}\text { Unlabeled }^{\mathrm{a}} \text { Cast Iron } \\
\text { 2D }\end{array}$ & $\begin{array}{l}\text { Cap under Wash Sink } \\
\# 3\end{array}$ & Unlabeled $^{\mathrm{a}} 2 \mathrm{~A}$ & \\
\hline $\begin{array}{l}\text { Unlabeled }^{\mathrm{a}} \text { Cast Iron } \\
2 \mathrm{E}\end{array}$ & $\begin{array}{l}\text { Cap under Wash Sink } \\
\# 2\end{array}$ & Unlabeled $^{\mathrm{a}} 2 \mathrm{~A}$ & \\
\hline $\begin{array}{l}\text { Unlabeled }^{\mathrm{a}} \text { Cast Iron } \\
2 \mathrm{~F}\end{array}$ & $\begin{array}{l}\text { Capped Floor Drain } \\
\# 11\end{array}$ & Unlabeled $^{\mathrm{a}} 2 \mathrm{~A}$ & \\
\hline $\begin{array}{l}\text { Unlabeled }{ }^{\mathrm{a}} \text { Cast Iron } \\
2 \mathrm{G}\end{array}$ & $\begin{array}{l}\text { Cap under Wash Sink } \\
\# 1\end{array}$ & Unlabeled $^{\mathrm{a}} 2 \mathrm{~A}$ & \\
\hline $\begin{array}{l}\text { Unlabeled }^{\mathrm{a}} \text { Cast Iron } \\
2 \mathrm{H}\end{array}$ & Unlabeled $^{\mathrm{a}} 2 \mathrm{~A}$ & 4" LD-1039C & \\
\hline
\end{tabular}

